\title{
The current status of major tick borne diseases in Zambia
}

\author{
Levi Hakwale MAKALA ${ }^{\mathrm{a}, \mathrm{b}}$, Peter MANGANI ${ }^{\mathrm{c}}$, Kozo FUJISAKI ${ }^{\mathrm{a}}$, \\ Hideyuki NAGASAWA ${ }^{\mathrm{a} *}$
}

\begin{abstract}
${ }^{a}$ National Research Center for Protozoan Diseases, Obihiro University of Agriculture and Veterinary Medicine, Inada-Cho, Obihiro, Hokkaido 080-8555, Japan

${ }^{b}$ Central Veterinary Research Institute, Balmoral, Lusaka, Zambia

${ }^{\mathrm{c}}$ Department of Research and Specialist Services, Animal Production and Health Sub-programme, Ministry of Agriculture, Food and Fisheries, Lusaka, Zambia
\end{abstract}

(Received 4 February 2002; accepted 6 August 2002)

\begin{abstract}
Tick-borne diseases occurring in Zambia are assuming more importance as they continue to be a major economic problem not only in Zambia, but in many parts of Eastern, Southern and Central Africa. The current control methods, which include the use of toxic acaricides to kill ticks, and the virulent sporozoite infection and treatment method have limitations. Recombinant vaccines, currently in their experimental stages, offer hope for the future. The use of acaricides is hampered by the development of acaricide resistance and live vaccines are dependent on cold chain facilities, which are a formidable obstacle in the poorly developed infrastructure in parts of Zambia where the vaccine is most needed. Amidst these drawbacks are the results of the recent research on parasites and vector recombinant vaccines which promise to circumvent these problems. The history, current status and attitudes regarding the control of these diseases, taking into account their complexity, are reviewed. The establishment of the well-designed Central Veterinary Research Institute (CVRI) and Japanese International Cooperation Agency (JICA) sponsored veterinary school, both have a potential for high quality research, with access to a wealth of specimens a veritable goldmine of research material. It is thus hoped that this review will stimulate the desire to maximize the value of the tick and tick-borne disease research in both Zambia and the international research community.
\end{abstract}

Anaplasma / Babesia / Cowdria / Theileria

Table of contents

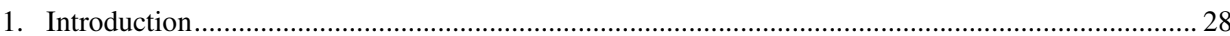

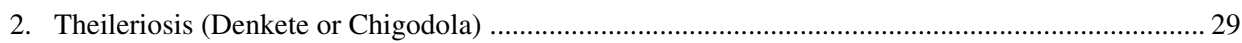

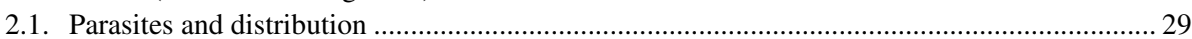

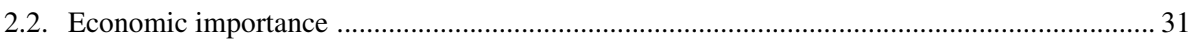

3. Babesiosis (Red water) and anaplasmosis (Gall sickness) ....................................................... 32

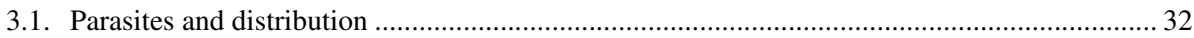

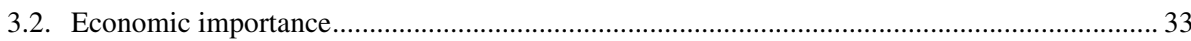

*Correspondence and reprints

Tel.: (81) 15549 5644; fax: (81) 15549 5643; e-mail: nrcpmi@ obihiro.ac.jp 


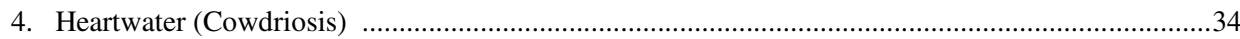

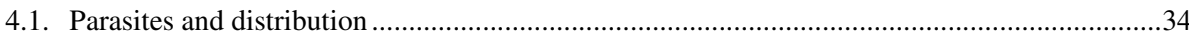

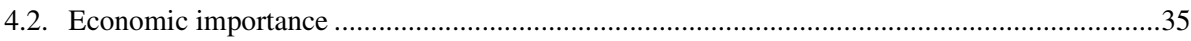

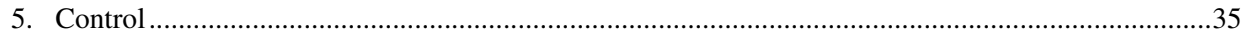

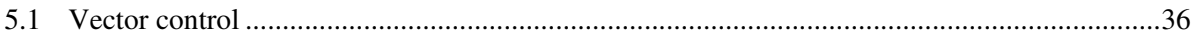

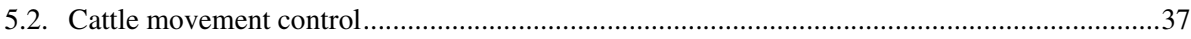

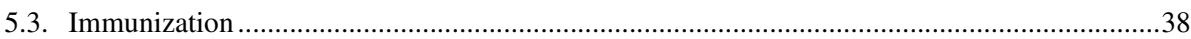

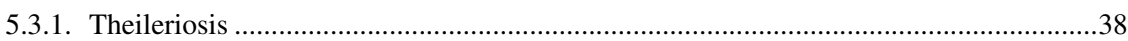

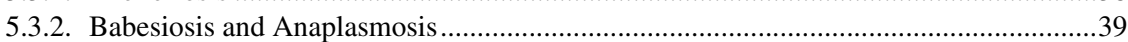

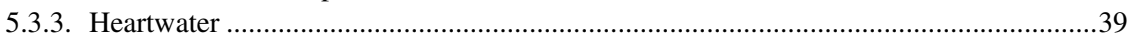

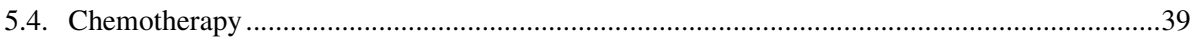

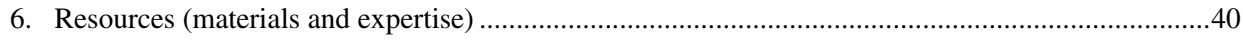

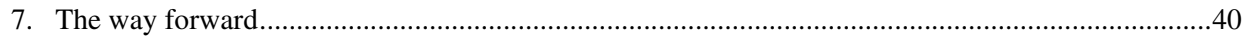

\section{INTRODUCTION}

Zambia is a land locked country situated in the tropics between latitude 8 and 18 degrees east and longitudes 22 and 34 degrees south, with a land area of about 752600 square kilometers and an estimated population of about 11 million as per the 2000 population census data. Livestock distribution is not even over the country, divided into 9 provinces for administrative convenience. The nine provinces of Zambia together with the countries neighboring Zambia are shown in Figure 1. It is estimated that in Zambia, the livestock sector comprises about 3 million heads of cattle, 82281 sheep, 953757 goats, 343195 pigs, 1695 donkeys, 874 horses and 1.5 million dogs [2]. Cattle are the most important type of livestock in Zambia. The traditional cattle are mainly the Sanga and Zebu. Although cattle dominate the livestock sector, small ruminants also play a commercial role in the traditional sector.

The past history of major protozoan diseases in Zambia itself is inseparable from that of tick borne diseases, which are of importance not only in Zambia, but also in many parts of Eastern, Central and Southern Africa and the world as a whole. Tick borne diseases (TBD) are still a major constraint to livestock production in developing countries. In cattle they are the cause of high morbidity and mortality, decreased meat and milk production and loss of draught power and manure together with the cost of control measures [2, 3]. They are also an impediment to the upgrading of indigenous breeds of cattle, sheep and goats, as well as the introduction of more productive exotic breeds. Ticks are the most important ecto-parasites in Zambia since they are responsible for transmitting diseases that cause the highest cattle mortalities compared to other diseases [1]. Besides their role as disease control vectors, ticks cause physical damage such as injury to hides and loss of blood through their feeding [99]. In addition, ticks inflict severe bite wounds on animals, which are prone to myiasis and act as a route of infection for a number of other disease causing agents [100, 103]. There are many diseases that are transmitted by ticks, but in domestic animals in Zambia and the neighboring countries within the South, Central and East African regions, particularly in cattle and small ruminants, the most important ones are Theileriosis (East coast fever/Corridor disease) also locally known in Zambia as Denkete (Southern Zambia) and Chigodola 


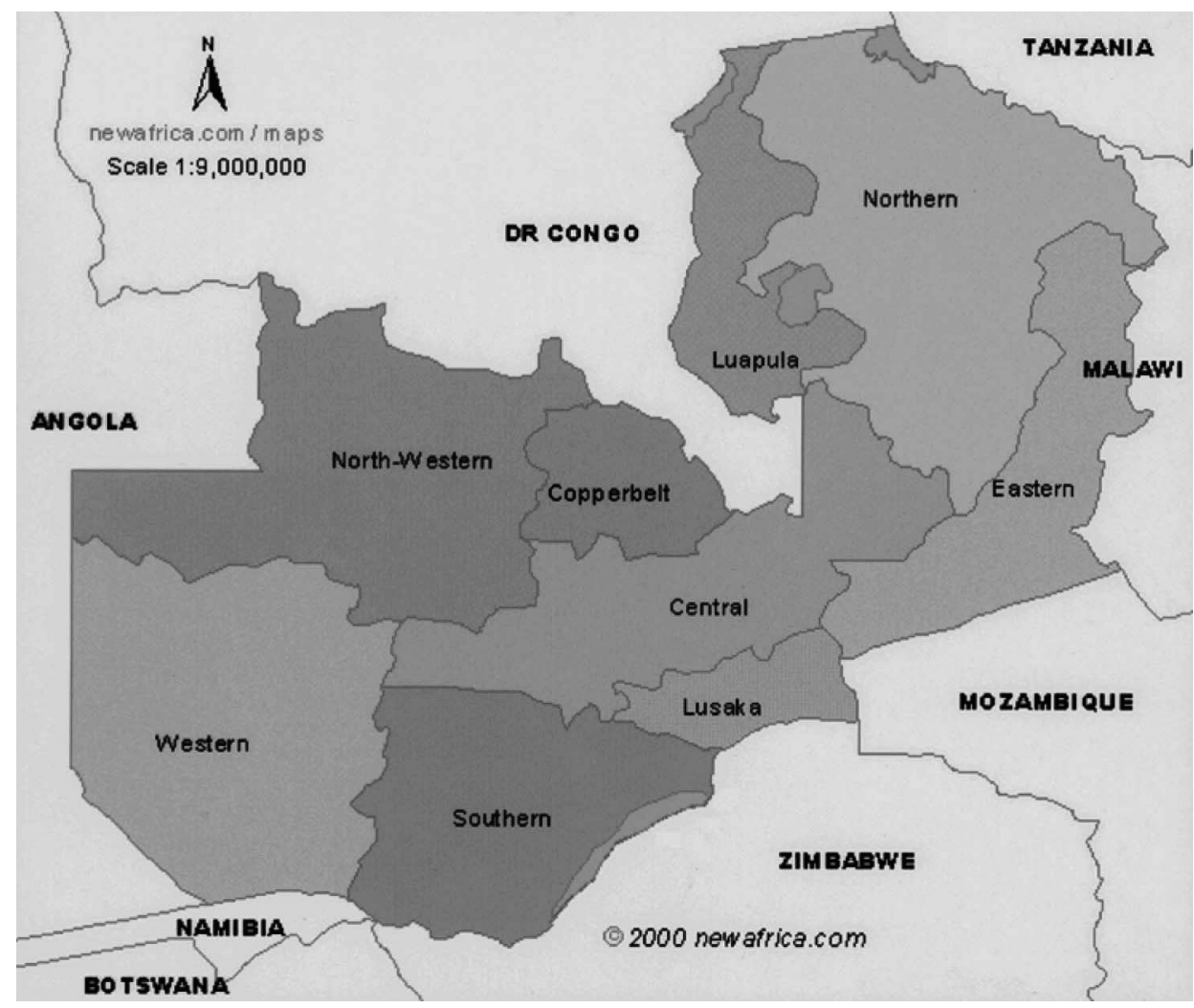

Figure 1. An administrative map of Zambia showing the land-locked status, neighboring countries and the location of the nine provinces of Zambia. Each province has a regional/provincial diagnostic laboratory overseen by the Central veterinary Research Station. Regional laboratories are further divided into district diagnostic laboratories. (Map supplied by 2000 newafrica.com)

(Eastern Zambia); Anaplasmosis (Gall sickness); Babesiosis (Red water); and Heartwater (Cowdriosis). A summary of the major tick-borne diseases for the period 1997-2000 are shown in Table I. This table shows that theileriosis is the most important tick-borne disease, causing significantly more deaths than the other tickborne diseases combined. All these tickborne diseases are present in over 10 countries in Eastern, Central and Southern Africa and moreover, in many cases the vectors are more widely distributed than the parasite, thus the potential danger of the diseases spreading to other areas cannot be overemphasized.

\section{THEILERIOSIS (DENKETE OR CHIGODOLA)}

\subsection{Parasites and distribution}

Theilerioses are protozoan infections of wild and domestic Bovidae occurring throughout much of the world that belong to the genus Theileria. Although the real origin of Theileriosis in Zambia is not known, the first case of Theileriosis was recorded in the Nakonde area of northern Zambia in 1922, and it is highly assumed that it originated from East Africa [69]. In Zambia, Theileriosis manifests itself in the form of a severe lympho-proliferative 
Table I. Summary of the major tick-borne diseases for the period 1997-2000. Data were obtained from papers referenced in the text.

\begin{tabular}{|c|c|c|c|c|c|c|c|c|}
\hline \multirow[t]{2}{*}{ Year } & \multicolumn{2}{|c|}{ Theileriosis } & \multicolumn{2}{|c|}{ Babesiosis } & \multicolumn{2}{|c|}{ Anaplasmosis } & \multicolumn{2}{|c|}{ Heartwater } \\
\hline & Cases & Deaths & Cases & Deaths & Cases & Deaths & Cases & Deaths \\
\hline 2000 & 3678 & 1443 & 802 & 70 & 690 & 404 & 231 & 104 \\
\hline 1999 & 9520 & 4526 & 10454 & 253 & 1782 & 531 & 380 & 142 \\
\hline 1998 & 11957 & 5430 & 21291 & 155 & 1779 & 510 & 251 & 104 \\
\hline 1997 & 7457 & 4516 & 15560 & 253 & 2669 & 753 & 646 & 312 \\
\hline Totals & 32612 & 15915 & 48107 & 731 & 6920 & 2198 & 1253 & 576 \\
\hline
\end{tabular}

disease known as the Corridor disease (CD), East Coast Fever (ECF) or January disease [17, 30, 39, 56, 71, 97, 106, 107]. Amongst the five Theileria species and subspecies that are known to exist in Zambia, the most economically important are T. parva parva and T. parva lawrencei $[28,31,70]$. Molecular DNA studies have however shown that the causative Theileria parva subspecies are indistinguishable from each other at the molecular level, although the disease syndromes they cause are quite distinct [28, 31, 64, 73, 74]. Theileria species in Zambia are summarized in Table II. Taurine (Bos Taurus) cattle, their crosses, and improved Zebu (Bos indicus) cattle originating in non-endemic areas are the most severely affected [58]. $\mathrm{CD}$ is widely spread in the Southern, Central, and Lusaka provinces and has recently been recorded in the Copper-belt province. ECF is present in the Northern and Eastern provinces of Zambia. However, this separation of "disease" into CD and ECF has been based on historical reports and not on current data indicating ECF as being important in Zambia.

The main vector of the T. Parva parasites is a three-host tick Rhipicephalus appendiculatus (R. appendiculatus) [7-11, 16, 62, $63]$ and Rhipicephalus zambeziensis ( $R$. zambeziensis) [28, 74], which are more widely distributed than the parasite [68], hence a potential danger of the disease spreading to other areas cannot be ruled out.
Within an infected area, the pattern of Theileriosis occurrence may take the form of either epizootic and enzootic occurrence or enzootic stability. The Theileria epidemiological situation in Zambia can be described as an endemic unstable zone in parts of the Eastern and Northern provinces. This situation is entirely defined by the less favorable climatic conditions for Rhipicephalus ticks in this part of its range. The result is a complex tick ecology, characterized by one or two tick generations a year and the occurrence of diapause in contrast to a year round presence of ticks in Kenya, Tanzania and Rwanda. A total of about 25000 Theileriosis cases were recorded by the Animal Production and Health Subprogram (APH) in 1991, out of which 2596 were ECF cases, with the Northern province recording 468 cases, while the Eastern province recorded 2128 cases [69]. Table I indicates the decreasing importance of ECF in 2000. Speculatively, this may have been due to under-reporting. On the contrary, this would mean that the then ongoing ECF vaccinations have begun to yield the desired result. The highest number of ECF cases in both provinces occurred between January and March [96]. The highest number of CD in the Southern province, were recorded during the month of January. Most of the recorded cases are based on the diagnosis demonstrated by the presence of schizonts (Koch blue bodies - KBB) in lymph node 
Table II. Tickborne disease parasite species in Zambia. Data were obtained from papers referenced in the text.

\begin{tabular}{|c|c|c|}
\hline Species & Disease caused & Vector \\
\hline T. parva parva & East coast fever (Chigodola) & R. appendiculatus \\
\hline \multirow[t]{2}{*}{ T. parva lawrencei } & Corridor disease (Denkete) & R. zambeziensis \\
\hline & & Rhipicephalus spp. \\
\hline \multirow[t]{2}{*}{ T. mutans } & Benign Theileriosis & Amblyomma spp. \\
\hline & & Rhipicephalus spp. \\
\hline T. verifera & Benign Theileriosis & Amblyomma spp. \\
\hline \multirow[t]{2}{*}{ T. taurotragi } & Benign Theileriosis & R. appendiculatus \\
\hline & & Rhipicephalus spp. \\
\hline \multirow[t]{4}{*}{ B. bigemina } & Red water (Babesiosis) & B. microplus \\
\hline & & B. decoloratus \\
\hline & & R. evertsi \\
\hline & & Biting arthropods (flies) \\
\hline B. bovis & Red water (Babesiosis) & As in B. bigemina \\
\hline B. canis & Canine Babesiosis & $R$. sanguineus \\
\hline B. caballi & Equine Babesiosis & As in B. bigemina \\
\hline \multirow[t]{3}{*}{ A. marginale } & Anaplasmosis (Gall sickness) & A. variegatum \\
\hline & & B. decoloratus \\
\hline & & R. evertsi \\
\hline \multirow[t]{2}{*}{ C. ruminantium } & Heartwater (Cowdriosis) & A. variegatum \\
\hline & & A. hebraeum \\
\hline
\end{tabular}

biopsy smears [36], spleen impressions and piroplasms in blood smears from clinically sick animals. Morzaria et al. [57, 59] at the International Livestock Research Institute (ILRI), Nairobi, Kenya have developed a highly sensitive and specific ELISA, which allows precise diagnosis of $T$. parva antigens and is currently being used in Zambia. This ELISA has been standardized and validated using defined experimental and field infection sera.

\subsection{Economic importance}

The economic impact of Theileriosis can be expressed in terms of mortality, loss of production (live-weight gain, milk production and draught potential), cost of control and in some cases restrictions placed on the movement of animals $[19,60,61$, 82]. In Zambia, apart from high treatment costs to farmers, the government spends substantial amounts of money annually for tick and tick-borne disease control, most of which is in the form of foreign exchange used for acaricide importation [17, 52-55]. Theileriosis also causes indirect economic losses. In the affected areas, farmers face substantial risk if they try to improve their herds by crossbreeding because the productive breeds of cattle are highly susceptible to the disease [24]. 
Table III. Host species distribution of Babesiosis in Zambia. Data were obtained from papers referenced in the text.

\begin{tabular}{lcccccccccccc}
\hline & \multicolumn{10}{c}{ Year } \\
\cline { 2 - 12 } Species & 86 & 87 & 88 & 89 & 90 & 91 & 92 & 93 & 94 & 95 & 96 & Totals \\
\hline Bovine & 4 & 4 & 1 & 3 & 6 & 5 & 6 & 3 & & & 1 & 33 \\
Caprine & & & 1 & 1 & & & & & & & & 2 \\
Equine & 1 & 1 & 1 & & 4 & & & & 1 & & & 8 \\
Canine & & & & & 2 & & & & & & 2 \\
\hline Totals & 5 & 5 & 3 & 4 & 12 & 5 & 6 & 3 & 1 & & 45 \\
\hline
\end{tabular}

\section{BABESIOSIS (RED 3WATER) AND ANAPLASMOSIS (GALL SICKNESS)}

\subsection{Parasites and distribution}

Bovine Babesiosis and Anaplasmosis form part of a complex of diseases sharing the feature of being predominantly transmitted by ticks. In many cases, they have been shown to occur as a mixed infection [25, 26, 32, 81]. In Zambia, Babesiosis and Anaplasmosis count amongst the most important of all TBD. They are impediments to the development of livestock industries in Southern, Central and Eastern Africa [48]. In Zambia two species of Babesia, B. bovis and $B$. bigemina are recognized as being of economic importance in cattle and small ruminants [34, 41, 80, 84]. However, B. canis has been reported in dogs in Zambia $[2,105,106]$. The data on the occurrence of $B$. equi and B. caballi infection in horses is obscure, since there is no appropriate and efficient reporting system. Moreover, equine Babesiosis, is important since it is a major obstacle to free international movement of horses out of Zambia. In the genus Anaplasma, only A. marginale infection is important in cattle in Zambia [48]. The infection caused by $B$. bigemina is more extensive than that caused by $B$. bovis and this may be attrib- uted to a wider vector range of B. bigemina. In focusing to develop a diagnostic tool, Morzaria et al. [57, 59] have developed highly and specific ELISA, which allow accurate and precise diagnosis of $B$. bigemina and A. marginale. These tests have also been standardized and validated using defined experimental and field sera.

The vectors and distribution of Babesia and Anaplasma species are summarized in Tables III to VI. Data were obtained from the Central Veterinary Research Institute (CVRI), which handles samples from all regions in the country. This may not necessarily be a true reflection of the pattern of occurrence of these disease vectors and parasites, but rather may be a consequence of under reporting, due to the difficulties encountered in submitting samples from regions to the CVRI. B. bovis, B. bigemina and $A$. marginale are present in all the provinces of Zambia $[2,48]$ and as well as in other parts of Southern Africa [21]. Boophilus microplus is the most important and wide spread vector for Babesiosis, while A. Marginale is transmitted by Amblyomma variegutum. However, there is an overlapping distribution of Boophilus decoloratus and Rhipicephalus evertsi, which also acts as a vector [25, 26]. Mechanical transmission by biting arthropods (biting flies) also occurs and is considered to be important as well. 
Table IV. Babesia species distribution in Zambia. Data were obtained from papers referenced in the text.

\begin{tabular}{|c|c|c|c|c|c|c|c|c|c|c|c|c|}
\hline \multirow[b]{2}{*}{ Species } & \multicolumn{12}{|c|}{ Year } \\
\hline & 86 & 87 & 88 & 89 & 90 & 91 & 92 & 93 & 94 & 95 & 96 & Totals \\
\hline B. bigemina & 1 & 2 & 1 & 3 & 3 & 4 & 4 & 2 & & & 1 & 21 \\
\hline B. bovis & 2 & 2 & 1 & & & & 2 & & & & & 7 \\
\hline B. caballi & & & & 1 & & & & & & & & 1 \\
\hline B. canis & 1 & & 1 & & 4 & & & 1 & 1 & & & 8 \\
\hline Unspecified & 1 & 1 & & & 5 & 1 & & & & & & 8 \\
\hline Totals & 5 & 5 & 3 & 4 & 12 & 5 & 6 & 3 & 1 & & 1 & 45 \\
\hline
\end{tabular}

Table V. Provincial distribution of anaplasmosis in Zambia. Data were obtained from papers referenced in the text.

\begin{tabular}{lccccccccccccc}
\hline & \multicolumn{10}{c}{ Year } \\
\cline { 2 - 13 } Province & 86 & 87 & 88 & 89 & 90 & 91 & 92 & 93 & 94 & 95 & 96 & 97 & Totals \\
\hline Lusaka & 1 & 4 & 22 & 9 & 3 & 6 & & & & 3 & 1 & 2 & 51 \\
Central & 7 & 8 & 14 & 13 & 24 & 18 & 4 & 6 & 8 & 1 & & 1 & 104 \\
Southern & 5 & 14 & 14 & 53 & 7 & 1 & 2 & 3 & & & 1 & & 100 \\
Eastern & & & & & & & & & & & & & \\
N/Western & & & & & & & & & & & & & \\
C/Belt & 1 & & 1 & 4 & 9 & 2 & 7 & & 1 & & & & 25 \\
Northern & 1 & 1 & 4 & 3 & 1 & 4 & 2 & & & 4 & & & \\
Luapula & 1 & & & & 3 & 2 & 2 & 4 & 2 & & & 1 & 15 \\
Western & & 1 & & 1 & & 1 & 1 & 4 & & & & & 8 \\
\hline Totals & 16 & 28 & 55 & 83 & 47 & 34 & 18 & 17 & 11 & 8 & 2 & 4 & 323 \\
\hline
\end{tabular}

\subsection{Economic importance}

Over 200000 cattle are exposed to Babesiosis and Anaplasmosis in Zambia, but this is not a true reflection of the number at risk to disease. The majority of the native Bos indicus and sanga type cattle in endemic areas are probably exposed to $B$. bovis, B. bigemina and $A$. marginale infections, but do not develop overt disease. This is partly due to the existence of a state of enzootic stability, whereby the cattle become naturally infected at an early age, when there is significant passively acquired and innate immunity and are immune to challenge later in life. Although the infections can have a serious effect on previously unexposed adult cattle, these breeds are generally more resistant than "Bos Taurus" breeds [14, 15], presumably because of a long association between the host and parasite. Exposure of the improved "Bos Taurus" cattle has been found to have disastrous consequences under the following conditions: when susceptible, high-risk cattle such as bulls and pregnant cows are imported into endemic areas (mortality rates of 50\% are not uncommon [48]); when cattle are exposed following the spread of ticks into 
Table VI. Host-species distribution of anaplasmosis in Zambia. Data were obtained from papers referenced in the text.

\begin{tabular}{lccccccccccccc}
\hline & \multicolumn{10}{c}{ Year } \\
\cline { 2 - 11 } Species & 86 & 87 & 88 & 89 & 90 & 91 & 92 & 93 & 94 & 95 & 96 & 97 & Totals \\
\hline Bovine & 10 & 18 & 46 & 41 & 90 & 38 & 17 & 15 & 16 & 8 & 2 & 4 & 305 \\
Caprine & & 2 & 1 & 4 & & & 1 & & 8 & & & & 16 \\
Ovine & & 1 & & & & & & & 1 & & & & 2 \\
Porcine & 1 & & 1 & & & & & 2 & & & & 4 \\
Antelope & 1 & & & & & & & 1 & & & & 2 \\
Duiker & & & & 1 & & & & & 1 & & & & 2 \\
Nilgai & 1 & & & & & & & 1 & & & & 2 \\
Bushback & & & & 1 & & & & & 1 & & & & 2 \\
Canine & & & & & 1 & & & & 1 & & & & 2 \\
Zebra & & & & 1 & & & & & 1 & & & & 2 \\
Unspecified & & & 3 & & & & & & 3 & & & \\
\hline Totals & 10 & 24 & 50 & 49 & 91 & 38 & 18 & 15 & 36 & 8 & 2 & 4 & 345 \\
\hline
\end{tabular}

previously non-infested areas; when infestation is introduced into a disease free vector population; and when enzootic stability fails to develop due to low tick transmission rates caused by, amongst others, ecological factors such as drought or the use of acaricides. Like Theileriosis, the economic impact of Babesiosis and Anaplasmosis can be expressed in terms of mortality, loss of production (live weight gain, milk production and draught potential), cost of control and in some cases restrictions placed on the movement of animals [50, 73].

\section{HEARTWATER (COWDRIOSIS)}

\subsection{Parasites and distribution}

Heartwater caused by Cowdria ruminantium is a rickettsial disease that affects domestic and wild ruminants in Zambia [32], the rest of Africa and the Carribean. The ticks, Amblyomma hebraeum and especially A. variegatum are the main vec- tors of heartwater in the agricultural areas of Zambia. The distribution patterns of both species in Zambia display anomalous features: the ticks occur in areas where the predicted climatic suitability for survival and development, as well as the densities of cattle (the most important domestic host) are, the lowest $[81,84,85]$. The only factor favoring the survival of the species in the areas in which they occur in Zambia is the presence of alternative wildlife hosts for the adult stage [80, 86, 88]. Their absence from more climatically favorable areas appears to be the result of intensive acaricide treatment of cattle over a long period of time and a historic absence of significant numbers of wild hosts. In Zambia, Heartwater is mainly a disease of cattle, although outbreaks in sheep and goats have been reported and recorded. The incidence of the disease is not necessarily associated with the presence of exotic and crossbreeds of cattle, but is mainly seen in areas where regularly dipped animals are in close proximity to indigenously kept cattle with no acaricidal treatment and also where game is frequently seen in cattle grazing 
Table VII. Host species distribution of Heartwater in Zambia. Data were obtained from papers referenced in the text.

\begin{tabular}{|c|c|c|c|c|c|c|c|c|c|c|c|c|}
\hline \multirow[b]{2}{*}{ Species } & \multicolumn{12}{|c|}{ Year } \\
\hline & 86 & 87 & 88 & 89 & 90 & 91 & 92 & 93 & 94 & 95 & 96 & Totals \\
\hline Bovine & 5 & & & 1 & 5 & 6 & 3 & & & & 195 & 215 \\
\hline Ovine & 3 & & & & & 2 & & & & & & 5 \\
\hline Caprine & & & & & & & & 1 & & & & 1 \\
\hline Totals & 8 & & & 1 & 5 & 8 & 3 & 1 & & & 195 & 221 \\
\hline
\end{tabular}

Table VIII. Monthly distribution of reported cases for Heartwater in Zambia during the year 1996. Data were obtained from papers referenced in the text.

\begin{tabular}{lcccccccccccc}
\hline Jan. & Feb. & Mar. & Apr. & May & Jun. & Jul. & Aug. & Sep. & Oct. & Nov. & Dec. & Total \\
\hline 0 & 6 & 27 & 22 & 23 & 37 & 24 & 24 & 18 & 3 & 6 & 5 & 195 \\
\hline
\end{tabular}

areas. The distribution of Heartwater by province, species and season is summarized in Tables VII to IX. Records of laboratory confirmed cases of Heartwater from the Central Veterinary Research Institute (CVRI) for the period 1986-1997 reveal that the disease occurs throughout the country. The disease is believed to be responsible for numerous deaths occurring throughout the year, but especially during the rainy season from March to September [43, 101, 102] (Tab. VIII). This again, however, may not necessarily be a true reflection of the pattern of occurrence of Heartwater in Zambia, but simply a consequence of under-reporting as has been shown by others [43].

\subsection{Economic importance}

In terms of TBD of cattle in Zambia, Heartwater, is surpassed in importance only by $\mathrm{ECF} / \mathrm{CD}$ and Anaplasmosis, caused by the $T$. parva and A. marginale group of organisms, respectively. In Zambia, Heartwater is regarded as a serious disease and many commercial farmers sustain great economic losses when they slacken their normal tick control practices [46, 47, 87]. Moreover, Heartwater is becoming increasingly important because of the changing agricultural practices in Zambia, including the frequent use of imported exotic breeds of livestock to improve productivity, extension of intensive livestock farming into areas that are ecologically marginal for vector survival and increasing movement of livestock between Heartwater free and endemic areas.

\section{CONTROL}

Joint efforts by the government of the republic of Zambia and assistance to the veterinary services of Zambia (ASVEZA), sponsored by the Belgium government have been ongoing for over a decade now. Before ASVEZA, another Belgium sponsored animal disease control project (BADCP), played a vital role in immunization against Theileriosis. Significant levels of donor support for the control of tickborne diseases have also been and continue to date to be received through the European Union (EU) funded Southern Africa Animal Disease Control Program (SAADCP), the Private and Co-operative Livestock Services Network Development Program (PCLSNDP) and the United 
Table IX. Provincial distribution of Heartwater in Zambia. Data were obtained from papers referenced in the text.

\begin{tabular}{|c|c|c|c|c|c|c|c|c|c|c|c|c|}
\hline \multirow[b]{2}{*}{ Species } & \multicolumn{12}{|c|}{ Year } \\
\hline & 86 & 87 & 88 & 89 & 90 & 91 & 92 & 93 & 94 & 95 & 96 & Totals \\
\hline Lusaka & 6 & & & & 3 & 2 & 2 & & & & & 13 \\
\hline Central & & & & & & 3 & & & & & 22 & 25 \\
\hline Southern & 1 & & & & 1 & 1 & & & & & 111 & 114 \\
\hline Eastern & & & & & & & & & & & 1 & 1 \\
\hline $\mathrm{N} /$ Western & 1 & & & 1 & & 2 & 1 & & & & 14 & 19 \\
\hline C/Belt & & & & & 1 & & & & & & 27 & 28 \\
\hline Northern & & & & & & & & 1 & & & 1 & 2 \\
\hline Luapula & & & & & & & & & & & & \\
\hline Western & & & & & & & & & & & 19 & 19 \\
\hline Totals & 8 & & & 1 & 5 & 8 & 3 & 1 & & & 195 & 221 \\
\hline
\end{tabular}

Nations (UN) Food Agricultural Organization (FAO). There are four major approaches to the control of tick-borne diseases in Zambia [7, 8, 18]: vector control; cattle movement control; chemotherapy; and immunization [44]. However, there are problems associated with each control approach.

\subsection{Vector control}

Currently in Zambia, conventional acaricide treatment of cattle for tick control by dipping, spraying or use of pour-on formulations is widely used $[68,69,79,82,83$, 88]. Recent studies have also shown that aqueous formulations of entomogenous fungi may be promising biosectides for tick control [34]. Other parallel studies have taken a more indirect approach to using microorganisms to control ticks [76, 113]. Additionally, natural pathogens of ticks, for example, nematode worms have also been shown to be effective for tick control [29]. However, all these are in the experimental stages. The types of chemicals used for tick vector control are summarized in Table X. Vector control is associated with the following problems: the high cost of acaricides; vulnerability of tick control pro- grams to political and economic instability $[11,52-54,78,83]$; acquired resistance to acaricides in Zambia and many other countries $[4,5,27,40-42,92,94,95,102,108$, 109]; destabilization of the endemic stability; environmental pollution and residues in animal products [35, 110-112]. More studies to better understand the resistance mechanisms in ticks and their diagnosis need to be carried out. In cases where Theileriosis, Heartwater, Babesiosis and Anaplasmosis are endemic, disease control rather than eradication is the only realistic option, as is currently the case in Zambia. Eradication is unlikely to be feasible except in ecologically isolated areas and advanced countries with the necessary resources. This is particularly true in the case of Anaplasmosis and Theileriosis with their domestic and wild reservoirs and a variety of vector species. An alternative approach of learning to live with ticks and exploiting naturally occurring host resistance has been advocated in Zambia and other third-world tropical countries, where there are major problems of tick-borne diseases, especially in highly productive exotic stock, which require very intensive dipping. The increase in legislation to combat the detrimental effect of residues of acaricides on 
Table X. The most common acaricides used for tick control in Zambia. Data were obtained from papers referenced in the text.

\begin{tabular}{lcc}
\hline Common name & Active ingredient & Chemical category \\
\hline Grenade & Cyhalothrin 5\% & Synthetic Pyrethroid \\
Triatix/Milbitraz & Amitraz 12.5\% & Formamidine \\
Decatix & Deltamethrin 5\% & Synthetic Pyrethroid \\
Camphechlor & Toxaphene 75\% & Organochlorine \\
Delnav & Dioxathion & Organophosphorus Compound Group I \\
Bac-dip & Quintiofos & Organophosphorus Compound Group I \\
Stelladone & Chlorofenviphos & Organophosphorus Compound Group II \\
Supona 100EC & Pyrethrin & Organophosphorus Compound Group II \\
Kupe greese & Coumaphos & Organophosphorus Compound Group II \\
Cethion 100EC & Chlorpyrinfosmethyl & Organophosphorus Compound Group II \\
Asuntol & Chlorpyrinfosmethyl & Organophosphorus Compound Group II \\
Super-dip & Chlorfenviphos 110\% & Organophosphorus Compound Group II \\
Supa-dip & Bromosethyl & Organophosphorus Compound Group III \\
Supatox & Bromosethyl & Organophosphorus Compound Group III \\
\hline
\end{tabular}

the environment, have emphasized the need to assess a variety of alternatives to tick vector control. There is an Australian tick vaccine already on the market, Bm 86 vaccine TickGARD (PLUS) against infestations with the cattle tick B. microplus [13, 20,33]. There is evidence for a strong cross protection with $B$. decolaratus, $H$. anatolicum and Hyalomma dromedarri, but with little effect on R. appendiculatus or Amblyoma variegatum. Vaccination with the $\mathrm{Bm}$ 86 vaccine has been shown to induce an over $60 \%$ reduction in tick numbers in the field over one generation, and a $72 \%$ reduction in laboratory measures of the reproductive efficiency of ticks. Future control options for ticks and tick-borne deseases in Zambia must be determined by economics and will be strongly influenced by the commercialisation of new control technologies that are currently being developed. Immunological protection of hosts against tick infestation at present appears to be the most practically sustainable alternative tick control method to the current use of acaricides that is riddled with serious limitations. The current focus of tick vaccine research is the identification, cloning and in vitro production of recombinant tick vaccine candidate antigens. There is a need to conduct research on the multi-host tick species that are more widespread in Zambia in order to develop an effective and protective tickvaccine for Zambia and the neighboring regions.

\subsection{Cattle movement control}

Regulation and control of livestock movement is one of the most important means of reducing the spread of diseases. In this regard, checkpoints have been constructed in strategic locations on each of the major arterial roads linking the most important cattle producing areas, marketing and processing infrastructure throughout the country. Moreover, orientation 
workshops have been organized to stimulate stakeholder participation in the control of livestock movement and with a view to reduce illegal stock movement and thefts as well as to introduce a workable animal identification system that may enable tracing back diseases to their place of origin. Current operations at checkpoints are not smooth due to the lack of logistical support to facilitate rapid and accurate responses to possible emergencies. However, the checkpoints have been a source of valuable data and information [2].

\subsection{Immunization}

\subsubsection{Theileriosis}

Currently immunization by the infection and treatment method using live vaccines based on infective sporozoite stages of the parasites is so far the most prominent method [7, 8, 28, 45, 58, 65-67, 89-91]. In this regard, the Katete and Chitongo stocks have successfully been used in the Eastern and Southern Provinces of Zambia, respectively. Sporozoites are inoculated in cattle with simultaneous administration of long-acting formulations of oxy-tetracyclines. However, the cost of the antibiotics makes it an expensive method as well. However, in Zambia, despite the government's subsidy of the cost of immunizations, most farmers are still unable to pay though willing to participate. Studies have shown that immunized cattle are protected against challenge provided the appropriate parasite stocks are used [91, 112]. It is also known that immunized cattle as well as those that recover naturally from ECF/ CD are carriers of the infection and therefore, can serve as a source of infection for others $[22,23,39,45,112]$. These vaccines are poorly adopted in the region, mainly because of problems associated with the use of live parasites. Moreover, there is a possibility that the live immunization method may introduce new stocks that might break through the animals immune system to local parasite strains.
From this viewpoint, studies need to be performed in order to determine the biological impact of introducing new parasite stocks in the epidemiology of Theileriosis and long term efficacy of live vaccines.

An alternative method of immunization is based on an experimental recombinant antigen (p76) that has been developed [72]. The efficacy of the vaccine is being evaluated under field challenge in Kenya. This development represents a potential control of Theileriosis and the idea can be extended to other tick-borne diseases in the region. The development of attenuated and recombinant vaccines from parasites to replace the infection and treatment method of immunization would represent a significant advance in practical terms $[49,67,69,93$, $104,110,111]$. The fact that animals can be protected using a subunit vaccine provides cause for optimism. However, since a vaccine based on a single antigen may not be sustainable under field conditions, a search for schizont antigens that induce protective cell-mediated immune responses continues. The current research on recombinant vaccines is promising. It is expected that the ultimate vaccine against Theileriosis and other tickborne diseases will incorporate a cocktail of several antigens derived from sporozoite and schizont stages, thus contributing to lifelong, protective and robust immunity. Nambota et al. [69] clearly showed that Theileriosis is a major constraint to the development of the livestock industry in Zambia and other parts of Africa [60]. Recently, the Zambian governments concerned with the tick borne disease situation in the southern province, led to the presidential pledge of 2 billion Zambian Kwachas, to launch the Southern province animal disease control revolving fund. This facility is meant for controlling animal diseases in the Southern province. Unfortunately, difficulties have been encountered in using these funds. More groundwork, and preparation need to be put into place to ensure maximum fund utilization. 


\subsubsection{Babesiosis and Anaplasmosis}

In Zambia, control of Babesiosis and Anaplasmosis is mainly achieved by chemotherapy and or chemoprophylaxis and vector control $[38,77]$ and less by immunization. The latter is restricted to some commercial farms, but it is not common practice. The reported success of immunization using tick fever vaccines in Australia [12], Paraguay [13] and South Africa [21] represents a potential for the control of babesiosis and Anaplasmosis in Zambia. In these countries, Babesia strains have been shown to provide good protection against field challenge and were safe to use in highly susceptible cattle. Anaplasma strains have not, however, been proven to be safe as is desirable for safety trials nor, have they provided good protection as with the Babesia strains in the efficacy trials. Similar studies using local Babesia and Anaplasma strains need to be carried out to come up with a protective and safe vaccine for Zambia and the surrounding regions.

\subsubsection{Heartwater}

There are currently ongoing trials of inactivated elementary body vaccine against Heartwater at Lutale, in the central province of Zambia ([6, 42], personnal communication). An inactivated elementary body vaccine is being developed for commercialization by the University of Florida/ USAID/ SADC Heartwater research project in Harare, Zimbabwe. Vaccines were made from cell cultures inactivated with Beta-propiolactone and mixed with the commercial montanide ISA 50 adjuvant. Field trials were carried out in Zimbabwe, Botswana, South Africa and Zambia, using a vaccine based on the Zimbabwean Mbizi isolate of Cowdria ruminantium, which has been shown to cross protect against a variety of field isolates, and in Botswana, South Africa and
Zambia, also using vaccines based on isolates obtained locally. The success of this trial will determine as to whether the vaccine can be used in all heartwater areas of Zambia and the SADC region [75]. More research must be conducted to identify a more suitable adjuvant and isolate or a cocktail of isolates as well as to improve the level of protection. The infection and treatment method of immunization against Heartwater is rarely used in Zambia.

\subsection{Chemotherapy}

In Zambia, drugs are used to treat cases of Heartwater, Theileriosis, Babesiosis and Anaplasmosis in addition to vector control $[38,77]$ and less by immunization. Drugs for use in chemotherapy or chemoprophylaxis of most tickborne diseases are readily available. Chemotherapy is actively used in the case of Babesiosis and Anaplasmosis. It is generally agreed that chemotherapy is not a control strategy, but rather a last resort when control strategies prove ineffective. Ideally, the three methods should be integrated to make the most cost effective use of each and also to exploit the breed resistance and the development and maintenance of enzootic stability $[37,39]$. No single method is likely adequate to control the complex problem of these and other TBD in Africa and elsewhere [73, 112]. However, the current Zambian approach is new, based on integrated strategies that encompass the following: selection of disease and tick resistant cattle [98, 99]; exploitation of enzootic stability; use of acaricides only when economically justified in relation to the direct effects of ticks on livestock production $[10,19,38$, $51,84,85]$. The major problems that affect chemotherapy as a control strategy are the difficulties encountered in the early diagnosis of the disease when chemotherapy is most likely to be active, and the high cost of the drugs, which the majority of traditional farmers cannot afford. 


\section{RESOURCES (MATERIALS AND EXPERTISE)}

At the Central Veterinary Research Institute (CVRI), and most if not all regional and district diagnostic laboratories, limited material for diagnosis and research as well as adequate funding to acquire these materials have been the main problem. In most laboratories, only basic microscopic diagnosis can be performed. However, two regional laboratories in Mazabuka and Chipata are exceptions because they are equipped well enough to conduct ELISA and IFAT on most tickborne diseases, using recently developed technology. Moreover, the Chipata and Mazabuka laboratories are actively involved in the well-funded ASVEZA tick and tick-borne disease control program with special emphasis on Theileriosis, which has been ongoing for over a decade. In addition, the Japanese Government built University of Zambia School of Veterinary medicine is well equipped and also offers modern diagnostic and research facilities. In terms of staff, from an establishment of 1146 for both research and field services staff, there are 146 professional posts (research and field veterinary officers, biologists), supported by a 983 member technical staff (laboratory technicians and assistants). The current numbers of field and research staff may apparently be sufficient, but the level of expertise needs to be improved in relation to the predominant tick and tick-borne diseases in the country.

\section{THE WAY FORWARD}

The main objective of the Animal Production and Health Subprogram (APH) as stated in the Agriculture Sector Investment Program (ASIP) document [2] is to improve the productive efficiency of the livestock sub-sector, particularly the traditional sector, which accounts for $82 \%$ of the nations livestock population.
Currently, Zambia is infested with a vast array of multi-host ticks, which spend most of the time off the host with short feeding periods ranging from 4-10 days. The traditional approach to kill these ticks during infestation has been chemical control using dips and sprays and in the last decade and for the tick-borne diseases, immunization using live vaccines by the infection and treatment method has particularly been used. However, the rising costs of acaricides, resistance and environmental contamination coupled with cold chain dependent live vaccine immunizations, have made it almost impossible to use these methods on a regular basis according to the pest and disease problem in third world tropical countries where tick associated problems are more pronounced. Some lessons may be learned from the Zimbabwean, Australian and Caribbean successful experiences, which have demonstrated that with total commitment of all parties and adequate financial backing and implementation of appropriate legislation agreed upon by all parties, intensive tick and tickborne disease control can be effectively maintained. The adoption of an intensive tick and tick-borne disease control policy has partly failed in Zambia not because of inappropriate technologies, but because of conflicting political and institutional agendas as well as inadequate financial support associated with unprofitable livestock industries. This has necessitated the search for alternative tick and tick-borne disease control methods on an integrated approach to pest and disease management. For this reason, vaccination against ticks and tickborne diseases using recombinant antigen vaccines are being studied in the hope that Zambia's future control strategy will involve only the economically effective and justifiable acaricide application in conjunction with the promising recombinant antigen vaccines. The Zambian approach should be to consider the options of tick and tick-borne disease control carefully for each program separately taking into account the prevailing epidemiological 
settings and parasite/vector population dynamics using only proven technical methods with the enforcement of appropriate legislation and good management.

\section{ACKOWLEDGEMENTS}

We are indebted to the Japanese Society for the Promotion of Science (JSPS) for financial support. The first author is supported by a research fellowship from JSPS for young scientists. The authors wish to thank the Animal production and Health Sub-program, Lusaka, Zambia for helpful advice, which has been invaluable in the production of the present review. The first author was Chief Veterinary Research Officer for the Ministry of Agriculture Food and Fisheries (MAFF) at CVRI, Balmoral, Lusaka, Zambia (19972000).

\section{REFERENCES}

[1] Anon A.G., A practical field manual, Vol. 2, Tick-borne Disease Control, in: Ticks and Tick-borne Disease control, Rome, 1984, p. 457.

[2] Animal production and Health subprogram (APH), Central Veterinary Research Institute (CVRI) Annual reports, MAFF, Lusaka, Zambia, 1986-2000.

[3] Agricultural sector Investment Programme (ASIP) for the Animal Production and Health sub-programme (APH), A new approach to agriculture in Zambia, MAFF, Lusaka, Zambia, 1994.

[4] Baker J.A.F., Miles J.O, Robertson W.D., Stanford G.D., Taylor R.J., The current status of resistance to organophosphorus ixodicides by the blue tick, Boophilus decoloratus (Koch) in the republic of South Africa and Transkei, J. S. Africa Vet. Assoc. 49 (1978) 327-333.

[5] Baker J.A.F., Miles J.O., Robertson W.D., Resistance to certain organophosphorus ixodicides in the bont tick Amblyomma habraeum in the Republic of South Africa and Swaziland, J. S. Africa Vet. Assoc. 49 (1978) 337-341.

[6] Barbet A.F., Whitmire W.M., Kamper S.M., Simbi B.H., Ganta R.R., Moreland, A.L., Mwangi, D.M., McGuire, T.C., Mahan, S.M., A subset of Cowdria ruminantium genes important for immune recognition and protection, Gene 275 (2001) 287-298.
[7] Berkvens D.L., Geysen D.M., Brandt J.R., Comments on the paper "Sustainable tick and tick-borne disease control in livestock improvement in developing countries", Vet. Parasitol. 77 (1998) 211-215.

[8] Berkvens D.L., Geysen D.M., Chaka G., Madder M., Brandt J.R., A survey of the ixodid ticks parasitizing cattle in the Eastern Province of Zambia, Med. Vet. Entomol. 12 (1998) 234-240.

[9] Berkvens D.L., Pegram R.G., Brandt J.R., A study of the diapausing behaviour of Rhipicephalus appendiculatus and $R$. zambeziensis under quasi-natural conditions in Zambia, Med. Vet. Entomol. 9 (1995) 307-315.

[10] Berkvens D.L., Re-assessment of tick control after immunization against East Coast fever in the Eastern Province of Zambia, Ann. Soc. Belg. Med. Trop. 71 (1991) 87-94.

[11] Billiouw M., Mataa L., Marcotty T., Chaka G., Brandt J., Berkvens D.L., The current epidemiological status of bovine Theileriosis in Eastern Zambia, Trop. Med. Int. Health. 4 (1999) A28-A33.

[12] Bock R.E., de Vos A.J., Immunity following use of Australian tick fever vaccine: a review of the evidence, Aust. Vet. J. 79 (2001) 832-839.

[13] Brizuela C.M., Ortellado C.A., Sanabria E., Torres O., Ortigosa D., The safety and efficacy of Australian tick-borne disease vaccine strains in cattle in Paraguay, Vet. Parasitol. 76 (1998) 27-41.

[14] Callow L.L., Dalgliesh R.J., Development of effective and safe vaccination against Babesiosis and Anaplasmosis in Australia. Proceedings of a symposium held at the 15th annual conference of the Australian Veterinary Association, Townsville, 1980, pp. 4-8.

[15] Callow L.L., Protozoan and Rickettsial diseases, in: Animal Health in Australia, Vol. 5, Canberra, Australian Government Publishing Services, 1984, pp. 1-264.

[16] Chaka G., Billiouw M., Geysen D.M. Berkvens D.L., Spatial and temporal variation in Rhipicephalus appendiculatus size in eastern Zambia, Trop. Med. Int. Health. 4 (1999) A43-A48.

[17] Chizyuka G.H.B., Mangani P.M.C., Theileriosis in Zambia, in: Irvin A.D. (Eds.), Immunization against Theileriosis in Zambia, ILRAD, Nairobi, 1985, pp. 41-44.

[18] Chizyuka H.G., Mulilo J.B., Methods currently used for the control of multi-host ticks: their validity and proposals for future control strategies, Parassitologia 32 (1990) 127-132. 
[19] de Castro J.J., James A.D., Minjauw B., Di Giulio G.U., Permin A., Pegram R.G., Chizyuka H.G., Sinyangwe P., Long-term studies on the economic impact of ticks on Sanga cattle in Zambia, Exp. Appl. Acarol. 21 (1997) 3-19.

[20] de Vos S., Zeinstra L., Taoufik O. Willadsen P., Jongejan F., Evidence for the utility of the Bm86 antigen from Boophilus microplus in vaccination against other tick species, Exp. Appl. Acarol. 25 (2001) 245261.

[21] De Wall D.T., Anaplasmosis control and diagnosis in South Africa, Ann. N.Y. Acad. Sci. 916 (2000) 474-483.

[22] Dolan T.T., Immunizations to control Eas Coast Fever, Parasitol. Today 3 (1987) 4-6.

[23] Dolan T.T., Progress in the chemotherapy of Theileriosis, in: Irvin A.D. et al. (Eds.), Advances in the control of Theileriosis. Martinus, Nijhoff, The Hague, 1981, pp. 186-208.

[24] Dolan T.T., Young A.S., An approach to the economic assessment of ECF in Kenya, in: Irvin A.D., Cunningham M.P., Young A.S (Eds.), Advances in the control of Theileriosis, Proceedings of an international conference, 9-13th February, 1981, ILRAD, Nairobi, Martinus, Nijhoff, The Hague, 1981, pp. 412-415.

[25] Friedhoff K.T., Tick-borne diseases of sheep and goats caused by Babesia, Theileria, or Anaplasma spp. Parasitology 39 (1997) 99-109.

[26] Friedhoff K.T., Transmission of Babesia, in: Ristic M., Kreir J.P. (Eds.), Babesiosis of domestic animals and man, New York, Academic Press, 1988, pp. 23-52.

[27] Fujisaki K., Development of acquired resistance-precipitating antibody in rabbits experimentally infested with females of Haemaphysalis longicornis (Ixodidea: Ixodidae), Natl. Inst. Anim. Health Q (Tokyo) 18 (1978) 27-38.

[28] Geysen D., Contribution on the characterization of Theileria isolates and stocks in Zambia, International Consortium on Ticks and Tick-borne Diseases (ICTTD) Newsletter 4 (1997) 11-12.

[29] Glazer I., Alekseev E., Samish M., Factors affecting the virulence of entomopathogenic nematodes to engorged female Boophilus annulatus ticks, J. Parasitol. 87 (2001) 808812.

[30] Grootenhuis J.G., The role of the wildlife in the epidemiology of cattle theileriosis, in: Dolan T.T. (Ed.), Theileriosis in Eastern, Central and Southern Africa, Proceedings of a workshop on East Coast fever
Immunization, held in Lilongwe, Malawi, 20-22 September, Nairobi, ILRAD, 1988, pp. 129-136.

[31] Jongejan F., Musisi F.L., Moorhouse P.D., Snacken M., Uilenberg G., Theileria taurotragi in Zambia, Vet. Q. 8 (1986) 261263.

[32] Jongejan F., Perry B.D., Moorhouse P.D., Musisi F.L., Pegram R.G., Snacken M., Epidemiology of bovine babesiosis and anaplasmosis in Zambia, Trop. Anim. Health Prod. 20 (1988) 234-242.

[33] Jonsson N.N, Matschoss A.L., Pepper P., Green P.E., Albrecht M.S., Hungerford J., Ansell J., Evaluation of tickGARD(PLUS), a novel vaccine against Boophilus microplus, in lactating Holstein-Friesian cows, Vet. Parasitol. 88 (2000) 275-285.

[34] Kaaya G.P., Hassan S., Entomogeous fungi as promisisng bioesticides for tick control, Exp. Appl. Acarol. 24 (2000) 913-926.

[35] Keating M.I., Dioxathion (Delnav) residues in milk in Kenya, Trop. Anim. Health Prod. 19 (1987) 147-152.

[36] Koch R., Reiseberiche uber Rinderpest, Bubonenpest in Indien and Africa, Tsetse oder Surrakrankheit, Texasfieber, tropische Malaria, Schwarzwasserfieber, SpringerVerlag, Berlin, 1898.

[37] Lawrence J.A., de Vos A.J., Methods currently used for the control of Anaplasmosis and Babesiosis: their validity and proposals for future control strategies, Parassitologia 32 (1990) 63-71.

[38] Lemche J., Pegram R.G., Control of cattle ticks using flumethrin in central Zambia, Vet. Rec. 121 (1987) 110-111.

[39] Levine N.D., Veterinary Parasitology, Iowa State University Press, Ames, USA, 1985.

[40] Luguru S.M., Banda D.S., Pegram R.G., Susceptibility of ticks to acaricides in Zambia, Trop. Anim. Health Prod. 16 (1984) 21-26.

[41] Luguru S.M., Observations on the management of acaricides used to control ticks in the traditional cattle of Zambia, Bulletin of Animal Hlth. Prod. Afr. 33 (1985) 313-320.

[42] Mahan S.M., Smith G.E., Kumbula D., Burridge M.J., Barbet A.F., Reduction in mortality from heartwater in cattle, sheep and goats exposed to field challenge using an inactivated vaccine, Vet. Parasitol. 97 (2001) 295-308

[43] Mangani M.C.P., Heart water in Zambia. The tick-ler. A quarterly publication of the UF/USAID/SADC Heart water Research project, Vol. 2, No. 4, 1997. 
[44] Marcotty T., Billiouw M., Chaka G., Berkvens D., Losson B., Brandt J., Immunisation against East Coast Fever by the infection and treatment method: evaluation of the use of ice baths for field delivery and appraisal of an acid formulation of long-acting tetracycline, Vet. Parasitol. 99 (2001) 175-187.

[45] Maritim A.C., Young A.S., Lesan A.C., Ndungu S.G., Mutugi J.J., Stagg D.A., Theilerial parasites isolated from carrier cattle after immunization with Theileria parva by the infection and treatment method, Parasitology 99 (1989) 139-147.

[46] Martinez T.A., Meltzer M.I. Perry B.D., Burridge M.J., Mahan S.M., The effect of subclinical experimental Cowdria ruminantium infection on the health and reproductive performance of breeding ewes, Prev. Vet. Med. 41 (1999) 89-103.

[47] Martinez T.A., Meltzer M.I., Perry B.D., Burridge M.J., Mahan S.M., The effect of subclinical experimental Cowdria ruminantium infection in ewes on the growth and milk consumption of pre-weaning lambs, Prev. Vet. Med. 41 (1999) 105-118.

[48] McCosker P.J., The global importance of babesiosis, in: Ristic M., Kreier J.P. (Eds.), Babesiosis, Academic press, New York, 1981, pp. 1-24.

[49] McKeever D.J., Morrison W.I., Novel vaccines against Theileria parva: prospects for sustainability, Int. J. Parasitol. 28 (1998) 693-706.

[50] McLeod R., Kristjanson P., Economic impact of ticks and tick-borne diseases to livestock in Africa, Asia and Australia, in: report to the International Livestock Research Institute (ILRI), Nairobi, Kenya, July, 1999.

[51] Minjauw B., Otte J., James A.D., de Castro J.J., Sinyangwe P., Effect of different East Coast Fever control strategies on fertility, milk production and weight gain of Sanga cattle in the Central Province of Zambia, Exp. Appl. Acarol. 21 (1997) 715-730.

[52] Minjauw B., Otte M.J., James A.D., de Castro J.J., Sinyangwe P., Effect of different East Coast fever control strategies on disease incidence in traditionally managed Sanga cattle in Central Province of Zambia, Prev. Vet. Med. 35 (1998) 101-113.

[53] Minjauw B., Otte M.J., James A.D., de Castro J.J., Permin A., Di Giulo G., An outbreak of East Coast fever in a herd of Sanga cattle in Lutale, Central Province of Zambia, Prev. Vet. Med. 35 (1998) 143-147.

[54] Minjauw B., Otte M.J., James A.D., Epidemiology and control of east coast fever in Zambia. A field trial with traditionally managed Sanga cattle, Ann. N. Y. Acad. Sci. 849 (1998) 219-225.

[55] Minjauw B., Rushton J., James A.D., Upton M., Financial analysis of East Coast fever control strategies in traditionally managed Sanga cattle in Central Province of Zambia, Prev. Vet. Med. 38 (1999) 35-45.

[56] Morel P.C., Uilenberg G., The nomenclature of some Theileria species (Sporozoa, Babesioidea) of domestic ruminants (Authors translation), Rev. Elev. Méd. Vét. Pays. Trop. 34 (1981) 139-143.

[57] Morzaria S., Nene V., Bishop R., Musoke A., Vaccines against Theileria parva, Ann. N. Y. Acad. Sci. 916 (2000) 464-473.

[58] Morzaria S.P., Irvin A.D., Wathanga J., D'Souza D., Katende J., Young A.S., Scott J., Gettinby G., The effect of East Coast fever immunisation and different acaricidal treatments on the productivity of beef cattle, Vet. Rec. 123 (1988) 313-320.

[59] Morzaria S.P., Katende J., Musoke A., Nene V., Skilton R., Bishop R., Development of sero-diagnostic and molecular tools for the control of important tick-borne pathogens of cattle in Africa, Parassitologia 41 (1999) 73-80.

[60] Mukhebi A.W., Perry B.D., Kruska R., Estimating economic losses caused by Theileriosis and the economics of its control, Prev. Vet. Med. 12 (1992) 73-85.

[61] Mukhebi A.W., Wathanga J., Perry B.D., Irvin A.D., Morzaria S.P., Financial analysis of East Coast fever control strategies on beef production under farm conditions, Vet. Rec. 125 (1989) 456-459.

[62] Mulumba M., Speybroeck N., Berkvens D.L., Geysen D.M., Brandt J.R., Transmission of Theileria parva in the traditional farming sector in the Southern Province of Zambia during 1997-1998, Trop. Anim. Health Prod. 33 (2001) 117-125.

[63] Mulumba M., Speybroeck N., Billiouw M., Berkvens D.L., Geysen D.M., Brandt J.R., Transmission of Theileriosis in the traditional farming sector in the southern province of Zambia during 1995-1996, Trop. Anim. Health, Prod. 32 (2000) 303-314.

[64] Musisi F.L., Jongejan F., Pegram R.G., Isolation and transmission of Theileria mutans (Chisamba) in Zambia, Res. Vet. Sci. 36 (1984) 129-131.

[65] Musisi F.L., Production of Theileria parva stabilates for immunization against Theileriosis, in: Morzaria S., Williamson S. (Eds.), Live vaccine for Theileria parva: Deployment in Eastern, Central, and Southern Africa, Proceedings of an FAO, OAU-IBAR 
and ILRI workshop held at ILRI, Nairobi, Kenya, 10-12th March, 1997, ILRI, Nairobi, Kenya, 1999, pp. 45-55.

[66] Musoke A., Morzaria S., Nkonge C., Jones E., Nene V., A recombinant sporozoite surface antigen of Theileria parva induces protection in cattle, Proc. Natl. Acad. Sci. USA 89 (1992) 514-518.

[67] Musoke A.J., McKeever D., Nene V., Subunit vaccines for the control of tickborne diseases: implications for the future, Parassitologia 39 (1997) 131-137.

[68] Mwanaumo B., Dynamics of tick populations in the Southern province of zambia, in: Ghirotti M., Griffiths R.B., Mungaba F.N. (Eds.), World Health Organization, (WHO) Vet. Public. Hlth. Reports, Rome, Italy, 1987, pp. 9-14.

[69] Nambota A., Samui K., Sugimoto C., Kakuta T., Onuma M., Theileriosis in Zambia: etiology, epidemiology and control measures, Jpn. J. Vet. Res. 42 (1994) 1-18.

[70] Nambota A.M., Lovelace C.E., Chitambo H., Kakuda T., Sugimoto C., Onuma M., Characterization of some Theileria parva stocks from Zambia using monoclonal antibodies, J. Vet. Med. Sci. 59 (1997) 1-4.

[71] Neitz W.O., Corridor disease: a fatal focus of Theileriosis encountered in Zululand, Bull. Epizoot. Dis. Afr. 3 (1955) 121-123.

[72] Nene V., Gobright E., Bishop R., Morzaria S., Musoke A., Linear peptide specificity of bovine antibody responses to p67 of Theileria parva and sequence diversity of sporozoite-neutralizing epitopes: implications for a vaccine, Infect. Immun. 67 (1999) 1261-1266.

[73] Norval R.A., Lawrence J.A., Young A.S., Perry B.D., Dolan T.T., Scott J., Theileria parva: influence of vector, parasite and host relationships on the epidemiology of Theileriosis in southern Africa, Parasitology 102 (1991) 347-356.

[74] Norval R.A., Perry B.D., Young A.S., The epidemiology of Theileriosis in Africa, Academic Press, London, 1992.

[75] O'Callaghan C.J., Medley G.F, Peter T.F., Mahan S.M., Perry B.D., Predicting the effect of vaccination on the transmission dynamics of heartwater (Cowdria ruminantium infection), Prev. Vet. Med. 42 (1999) 17-38.

[76] Onofre S.B., Miniuk C.M., de Barros N.M. Azevedo J.L., Pathogenicity of four strains of entomopathogenic fungi against the bovine tick Boophilus microplus, Am. J. Vet. Res. 62 (2001) 1478-1480.

[77] Pegram R.G., Lemche J., Observations on the efficacy of ivermectin in the control of cattle ticks in Zambia, Vet. Rec. 117 (1985) 551-554.

[78] Pegram R.G., Wilson D.D., Hansen J.W. Past and present national tick control programs. Why they succeed or fail, Ann. N.Y. Acad. Sci. 916 (2000) 546-554.

[79] Pegram R.G., Getting a handle on tick control: a modern approach may be needed, Vet. J. 161 (2001) 227-228.

[80] Pegram R.G., Banda D.S., Ecology and phenology of cattle ticks in Zambia: development and survival of free-living stages, Exp. Appl. Acarol. 8 (1990) 291-301.

[81] Pegram R.G., Chizyuka, H.G., The impact of natural infestations of ticks in Zambia on the productivity of cattle and implications for tick control strategies in central Africa, Parassitologia 32 (1990) 165-175.

[82] Pegram R.G., James A.D., Oosterwijk G.P., Killorn K.J., Lemche J., Ghirotti M., Tekle Z., Chizyuka H.G, Mwase E.T., Chizyuka F., Studies on the economics of ticks in Zambia, Exp. Appl. Acarol. 12 (1991)9-26.

[83] Pegram R.G., Hansen J.W., Wilson D.D., Eradication and surveillance of the tropical bont tick in the Caribbean. An international approach, Ann. N.Y. Acad. Sci. 916 (2000) 179-185.

[84] Pegram R.G., Lemche J., Chizyuka H.G., Sutherst R.W., Floyd R.B., Kerr J.D., McCosker P.J., Effect of tick control on liveweight gain of cattle in central Zambia, Med. Vet. Entomol. 3 (1989) 313-320.

[85] Pegram R.G., Lemche J., Chizyuka H.G., Sutherst R.W., Floyd R.B., Kerr J.D., McCosker P.J., Ecological aspects of cattle tick control in central Zambia, Med. Vet. Entomol.3 (1989) 307-312.

[86] Pegram R.G., Perry B.D., Musisi F.L., Mwanaumo B., Ecology and phenology of ticks in Zambia: seasonal dynamics on cattle, Exp. Appl. Acarol. 2 (1986) 25-45.

[87] Pegram R.G., Oosterwijk G.P., The effect of Amblyomma variegatum on liveweight gain of cattle in Zambia, Med. Vet. Entomol. 4 (1990) 327-330.

[88] Peter T.F., Anderson E.C., Burridge M.J., Mahan S.M., Demonstration of a carrier state for Cowdria ruminantium in wild ruminants from Africa, J. Wildl. Dis. 34 (1998) 567575.

[89] Pipano E., Vaccination of cattle against Theileria annulata using culture-derived schizonts, in: Dolan T.T. (Eds.), Recent developments in the research and control of Theileria annulata. Proceedings of a workshop held at ILRAD, Nairobi, Kenya, 17-19th, September, 1990, ILRAD, Nairobi, Kenya, 1992,pp. 47-58. 
[90] Pipano E., Live vaccines against haemoparasitic diseases in livestock, Vet. Parasitol. 57 (1995) 213-231.

[91] Radley D.E., Infection and treatment method of immunization against Theileriosis, in: Irvin A.D. et al. (Eds.), Advances in the control of Theileriosis, Martinus, Nijhof, 1981, pp. 227-239.

[92] Rand K.N., Moore T., Sriskantha A., Spring K., Tellam R., Willadsen P., Cobon G.S., Cloning and expression of a protective antigen from the cattle tick Boophilus microplus, Proc. Natl. Acad. Sci. USA 86 (1989) 9657-9661.

[93] Riding G.A., Jarmey J., McKenna R.V., Pearson R., Cobon G.S., Willadsen P.A., Protective "concealed" antigen from Boophilus microplus. Purification, localization, and possible function, J. Immunol. 153 (1994) 5158-5166.

[94] Rinkanya F.G.R., Ongare J.O., Mwangi E.N., Ondongo F., Plunge dip trials of two chlorfenviphos formulations for tick control, the Kenya Veterinarian 7 (1981) 18-21.

[95] Rinkanya F.G.R., Tatchel R.J., Evaluation of the efficiency of different pour-on formulations against cattle ticks in Kenya, Trop. Pest Manage. 34 (1988) 324-327.

[96] Samui K., The epidemiology of Theileriosis in the Southern province of zambia, in: Ghirotti M., Griffiths R.B., Mungaba F.N. (Eds.), World Health Organization, (WHO) Vet. Public. Hlth. Reports., Rome, Italy, 1987, pp. 12-25.

[97] Schwabe C.W., Rieman H.P., Franti C.E., Epidemiology in veterinary practice, Philadelphia, Lea, Febiger (Eds.), 1977, pp. 12-21.

[98] Smith R.E., Mwase E.T., Heller-Haupt A., Trinder P.K., Pegram R.G., Wilsmore A.J., Varma M.G., Delayed-type hypersensitivity test for assessing tick-immune status of cattle in Zambia, Vet. Rec. 124 (1989) 583584.

[99] Smith R., Pegram R.G., Burt S., Killorn K.J., Oosterwijk G., Paterson A., Wilsmore A.J., Effect of dry season supplementation of Sanga cattle in Zambia, Trop. Anim. Health Prod. 23 (1991) 103-105.

[100] Snelson T.T., Animal ectoparasites and disease vectors causing major reductions in the world food supplies, FAO Plant Protec. Bull. 13 (1975) 103-114.

[101] Sonenshine D.E., Allan S.A., Peter T.F., McDaniel R., Burridge M.J., Does geographic range affect the attractant-aggregation-attachment pheromone of the tropical bont tick, amblyomma variegatum? Exp. Appl. Acarol. 24 (2000) 283-299.

[102] Sonenshine D.E., Internal anatomy: general features, biology of ticks, Vol. 1, Oxford University press, London, 1991, pp. 99-115.

[103] Sutherst R.W., Is the Australian pest management approach to tick control relevant to Africa, in: Whitehead G.B., Gibson J.D. (Eds.), Tick biology and control, Tick Research Unit, Rhodes University, Grahamstown, Zimbabwe, 1981, pp. 78-85.

[104] Uilenberg G., Dobbelaere D.A., de Gee A.L., Koch H.T., Progress in research on tick-borne diseases: Theileriosis and Heartwater, Vet. Q. 15 (1993) 48-54.

[105] Uilenberg G., Franssen F.F., Perie N.M., Spanjer A.A., Three groups of Babesia canis distinguished and a proposal for nomenclature, Vet. Q. 11 (1989) 33-40.

[106] Uilenberg G., Perie N.M., Lawrence J.A., de Vos A.J., Paling R.W., Spanjer A.A., Causal agents of bovine Theileriosis in southern Africa, Trop. Anim. Health Prod. 14 (1982) 127-140.

[107] Uilenberg G., Theilerial species of domestic livestock, in: Advances in the control of Theileriosis, A.D. Irvin, M.P. Cunningham, A.S. Young (Eds.), Martinus Nijhoff, London, 1981, pp. 4-37.

[108] Wharton R.H., Acaricide resistance and alternative methods of control, in: world animal review, FAO 20 (1976) 8-15.

[109] Wharton R.H., Cattle ticks in Australia. Recent research and prospect for control and eradication. Proceedings of a symposium held at the 15th annual conference of the Australian Veterinary Association, Townsville, 1980, pp. 30-35.

[110] Willadsen P., Kemp D.H., Vaccination with concealed antigen for tick control, Parasitol. Today 4 (1988) 196-198.

[111] Willadsen P., McKenna R.V., Riding G.A., Isolation from the cattle tick, Boophilus microplus, of antigenic material capable of eliciting a protective immunological response in the bovine host, Int. J. Parasitol. 18 (1988) 183-189.

[112] Young A.S., Groocock C.M., Kariuki D.P., Integrated control of ticks and tick-borne diseases of cattle in Africa, Parasitology 96 (1988) 403-432.

[113] Zhioua E., Browning M., Johnson P.W., Ginsberg H.S., LeBrun R.A., Pathogenicity of the entomopathogenic fungus Metarhizium anisopliae (Deuteromycetes) to Ixodes scapularis (Acari: Ixodidae), J. Parasitol. 83 (1997) 815-818. 
